
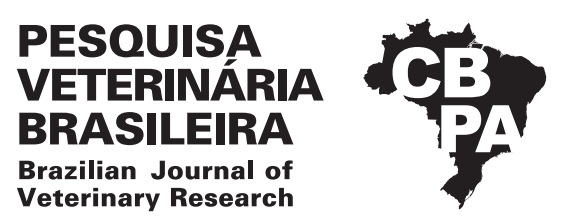

Pesq. Vet. Bras. 38(10):1989-1998, outubro 2018 DOI: 10.1590/1678-5150-PVB-5925

Original Article

ISSN 0100-736X (Print)

ISSN 1678-5150 (Online)

\title{
Pathological features of 78 metastatic or multicentric neoplasms involving the central nervous system in $\operatorname{dog} s^{1}$
}

\author{
Lilian C. Heck², Fernanda G. Cony ${ }^{2}$, Matheus V. Bianchi², David Driemeier², \\ Luciana Sonne ${ }^{2}$ and Saulo P. Pavarini ${ }^{2 *}$
}

\begin{abstract}
Heck L.C., Cony F.G., Bianchi M.V., Driemeier D., Sonne L. \& Pavarini S.P. 2018. Pathological features of 78 metastatic or multicentric neoplasms involving the central nervous system in dogs. Pesquisa Veterinária Brasileira 38(10)1989-1998. Setor de Patologia Veterinária, Faculdade de Veterinária, Universidade Federal do Rio Grande do Sul, Av. Bento Gonçalves 9090, Porto Alegre, RS 91540-000, Brazil. E-mail: saulo.pavarini@ufrgs.br

Secondary neoplasms affecting the central nervous system (CNS) may occur through blood flow or direct extension. This condition occurrence has increased both due to a longer life expectancy of dogs, as well as with the employment of chemotherapeutics, which may increase the survival period and, thus, the odds of the occurrence of metastasis. The aim of this study was to analyze the epidemiological features, such as the age, breed and sex of the animals affected, as well as the gross and microscopic findings of the metastasis from neoplasms involving the CNS of $78 \mathrm{dogs}$, and, based on the data, estimate the occurrence and frequency of the metastatic or multicentric neoplasms. Females (71.79\%) were most affected than males, with an average age of 9.5-years-old and a median of 10-years-old. Most of the cases had a multifocal distribution (73.07\%), and epithelial neoplasms (50\%) were the most common. Telencephalon was the most affected neuroanatomical region (61.1\%). Mammary neoplasms were the most frequent (47.44\%), followed by hemangiosarcoma (19.23\%), lymphoma (10.26\%) and melanoma (6.41\%). Less common neoplasms included osteosarcoma, histiocytic sarcoma and lung carcinoma (2.56\%). Mammary neoplasms were mainly composed of anaplastic and micropapillary carcinomas, of which only multifocal microscopic lesions were observed.
\end{abstract}

INDEX TERMS: Metastasis, multicentric neoplasms, central nervous system, dogs, brain tumors, neuropathology, secondary neoplasms, mammary carcinoma, hemangiosarcoma, pathology.

RESUMO.- [Aspectos patológicos e distribuição de 78 neoplasias metastáticas ou multicêntricas envolvendo o sistema nervoso central de caninos.] Neoplasias secundárias envolvendo o sistema nervoso central (SNC) podem ocorrer por via hematógena ou por extensão direta. A ocorrência desta condição vem aumentando devido à expectativa de vida mais longa dos cães, bem como através do uso de quimioterápicos, os quais podem ampliar a sobrevida e, portanto, as chances para a ocorrência de metástases. 0 objetivo deste estudo foi analisar os aspectos epidemiológicos, como idade, raça e sexo dos animais

\footnotetext{
${ }^{1}$ Received on May 24, 2018.

Accepted for publication on June 1, 2018.

${ }^{2}$ Setor de Patologia Veterinária, Faculdade de Veterinária, Universidade Federal do Rio Grande do Sul (UFRGS), Avenida Bento Gonçalves 9090, Agronomia, Porto Alegre, RS 91540-000, Brazil. *Corresponding author: saulo.pavarini@ufrgs.br
}

afetados, bem como caracterizar os achados macroscópicos e microscópicos de neoplasmas com metástases envolvendo o SNC de 78 caninos e, baseado nestes dados, estimar a ocorrência e a frequência de neoplasias metastáticas ou multicêntricas. Fêmeas $(71,79 \%)$ foram mais afetadas do que machos, com uma idade média de 9,5 anos e mediana de 10 anos. A maior parte dos casos apresentava distribuição multifocal (73,07\%), e neoplasias de origem epitelial (50\%) foram as mais frequentes. A localização neuroanatômica mais afetada foi o telencéfalo $(61,1 \%)$. As neoplasias mamárias foram as mais frequentes $(47,44 \%)$, seguidas por hemangiossarcoma (19,23\%), linfoma $(10,26 \%)$ e melanoma $(6,41 \%)$. Osteossarcoma, sarcoma histiocítico e carcinoma pulmonar $(2,56 \%)$ foram neoplasias menos frequentes. Os tipos de neoplasmas mamários mais observados foram o carcinoma anaplásico e o carcinoma micropapilar, nesses 
dois tipos as lesões eram multifocais e observadas somente na microscopia.

TERMOS DE INDEXAÇÃO: Metástase, neoplasias multicêntricas, sistema nervoso central, caninos, tumores encefálicos, neuropatologia, neoplasias secundárias, carcinoma de glândula mamária, hemangiossarcoma, patologia.

\section{INTRODUCTION}

Metastatic or secondary neoplasms of the central nervous system (CNS) are defined as intracranial or intramedullary neoplasms, which disseminate mainly hematogenously (Higgins et al. 2017). Yet, these neoplasms may also occur by local or direct extension to the CNS, as in nasal cavity carcinomas and facial/vertebral osteosarcomas (Cantile \& Youssef 2016). The occurrence of metastatic neoplasms to the CNS has increased in dogs, and it may be related to a longer life expectancy of these animals, since this condition occurs mostly in dogs older than nine-years-old, while primary neoplasms are observed in dogs with a broad age range (Higgins et al. 2017). Furthermore, the employment of chemotherapeutics as a treatment to neoplasms may increase the survival time of dogs, and, consequently, it may expand the odds of the establishment of a metastasis in the CNS (Fenner 1990).

Metastasis involving the CNS can be diagnosed through the association of the gross, microscopic and immunohistochemistry findings, which allow defining the origin of the metastatic neoplastic cells through a comparison with the cells present in the primary neoplasm site (Higgins et al. 2017). Unequal results have been reported in previous studies regarding the frequency of intracranial neoplasms in dogs, with primary neoplasms being more common in one study (Song et al. 2013) and secondary neoplasms in another (Snyder et al. 2008). However, the knowledge about the origin, distribution, frequency, age and breed predilection of these neoplasms is rare (Snyder et al. 2008). This study aims to determine the occurrence and estimate the frequency of metastatic or multicentric neoplasms involving the CNS in dogs submitted for necropsy from January 2006 to December 2016, and to describe the lesions distribution and to classify the dogs according to the age group, sex and breed.

\section{MATERIALS AND METHODS}

The database of the reports from necropsies performed in a veterinary pathology laboratory between January 2006 and December 2016 were reviewed in search for cases of dogs in which the cause of death was related to metastatic neoplasms, excluding those originated from the CNS. Among these metastatic neoplasms, the ones that involved the CNS were selected. The primary criterion for defining these neoplasms as metastatic was the observation of neoplastic cells in the CNS similar to the ones observed in distant sites (primary location), while lymphomas were defined as multicentric when it involved other tissues outside the CNS. Metastasis by direct extension was excluded from this study, and, thus, only neoplasms with distant origin from the CNS were selected. Data regarding the age, sex, breed and origin of the neoplasms were grouped and registered. Primary CNS neoplasms were also reviewed for comparison.

After cases were selected, the histological slides and formalin-fixed paraffin-embedded tissues were collected. The paraffin-embedded tissues were cut at $3 \mu \mathrm{m}$ thickness, placed on histological slides and stained by hematoxylin and eosin (HE). The location of the neoplasms was classified in seven neoplastic cell distributions: telencephalon, diencephalon, mesencephalon, rhombencephalon, corpus striatum, cerebellum and spinal cord. Microscopically, the neoplasms were divided in three patterns according to the neoplastic cells distribution: meningeal, intravascular and nodular. Frequency and distribution of metastatic neoplasms involving the CNS were defined, as well as the breeds, age ranges (minimum, maximum and mean) and sex of animals affected.

\section{RESULTS}

During the period analyzed, 4,643 dogs were necropsied, among which 883 had extra-neural malignant neoplasms as the cause of death. Of these, $78(8.83 \%)$ cases showed metastases from distant primary sites involving the CNS, corresponding to $1.67 \%$ of the causes of death in the period and to $57.77 \%$ of the neoplasms involving the CNS, while primary neoplasms accounted for $42.23 \%$ (total of 55 cases).

Neoplasms were from epithelial origin in 39 cases (50\%), mesenchymal in 28 (35.89\%), and in the remaining 11 cases $(14.11 \%)$ were mixed origin tumors. The mean age of the affected dogs was of 9.55-years-old (age range of two to 17 -years-old). Females $(71.79 \%, n=56)$ were most often affected than males $(28.2 \%, \mathrm{n}=22)$.

Mammary neoplasms were the most frequent metastatic neoplasms observed, followed by hemangiosarcoma, lymphoma, melanoma, osteosarcoma, histiocytic sarcoma and lung carcinoma. Other less frequent neoplasms occurred individually and accounted for seven cases. Total number, relative and absolute frequencies of metastatic neoplasms involving the CNS are illustrated in Table 1.

In 57 cases $(73.07 \%)$, the lesions were distributed multifocally in the CNS (more than one neuroanatomical region), while in 21 cases (26.93\%) the neoplasm was focal. The most common affected neuroanatomical site was the telencephalon $(64.1 \%, \mathrm{n}=50)$, followed by the cerebellum (26.9\%, $n=21)$ and diencephalon (24.3\%, n=19). Other

Table 1. Absolute, relative frequency and total number of metastatic CNS neoplasms

\begin{tabular}{|c|c|c|c|c|}
\hline Tumor & Metastasis & $\begin{array}{l}\text { Absolute } \\
\text { frequency }\end{array}$ & Total & $\begin{array}{l}\text { Relative } \\
\text { frequency }\end{array}$ \\
\hline Mammary neoplasms & 37 & 47.44 & 231 & 16.02 \\
\hline Hemangiosarcoma & 15 & 19.23 & 97 & 15.46 \\
\hline Lymphoma & 8 & 10.26 & 73 & 10.96 \\
\hline Melanoma & 5 & 6.41 & 39 & 12.82 \\
\hline Osteosarcoma & 2 & 2.56 & 69 & 2.90 \\
\hline Histiocytic sarcoma & 2 & 2.56 & 12 & 16.67 \\
\hline Lung carcinoma & 2 & 2.56 & 17 & 11.76 \\
\hline Nasal cavity carcinoma & 1 & 1.28 & 21 & 4.76 \\
\hline Cholangiocarcinoma & 1 & 1.28 & 33 & 3.03 \\
\hline Thyroid carcinoma & 1 & 1.28 & 17 & 5.88 \\
\hline Synovial sarcoma & 1 & 1.28 & 2 & 50.00 \\
\hline Apocrine gland carcinoma & 1 & 1.28 & 1 & 100.00 \\
\hline $\begin{array}{l}\text { Malignant peripheral nerve } \\
\text { sheath tumor }\end{array}$ & 1 & 1.28 & 10 & 10.00 \\
\hline Pheochromocytoma & 1 & 1.28 & 15 & 6.67 \\
\hline
\end{tabular}


neuroanatomical regions were less commonly affected. Mixed-breed dogs were the most affected $(37.18 \%, \mathrm{n}=29)$, followed by Rottweiler (15.38\%, n=12), Poodle (8.97\%, $n=7)$, Cocker (6.41\%) and Boxer (5.13\%, n=4).

\section{Mammary neoplasms}

Metastasis to the CNS of mammary neoplasms accounted for 37 cases, of which mixed-breed dogs were the most affected $(n=10)$, followed by Cocker $(n=4)$, Poodle $(n=4)$ and Rottweiler $(n=4)$. The mean age was of 10.5 -years-old (age range of five to 17-years-old), and females were mostly affected (36 cases).
Gross lesions in the CNS were observed in 18 dogs, which were characterized by focal (11 cases) (Fig. 1A) to multifocal (7 cases) white (Fig.1B and 1C) and, occasionally, red nodules. These cases involved the telencephalon $(n=16)$, cerebellum $(n=5)$, diencephalon $(n=3)$, corpus striatum $(n=2)$, mesencephalon $(n=2)$ and rhombencephalon $(n=1)$. The remaining cases (19/37) did not present any CNS gross lesions (Figure 1D show 10 anaplastic carcinomas and Figure 1E show 9 micropapillary invasive carcinomas). The lesion in these cases consisted of multifocal neoplastic cells inside blood vessels and, occasionally, extending to the neuropil, forming micrometastases $(n=14)$ or involving the leptomeninges $(n=6)$

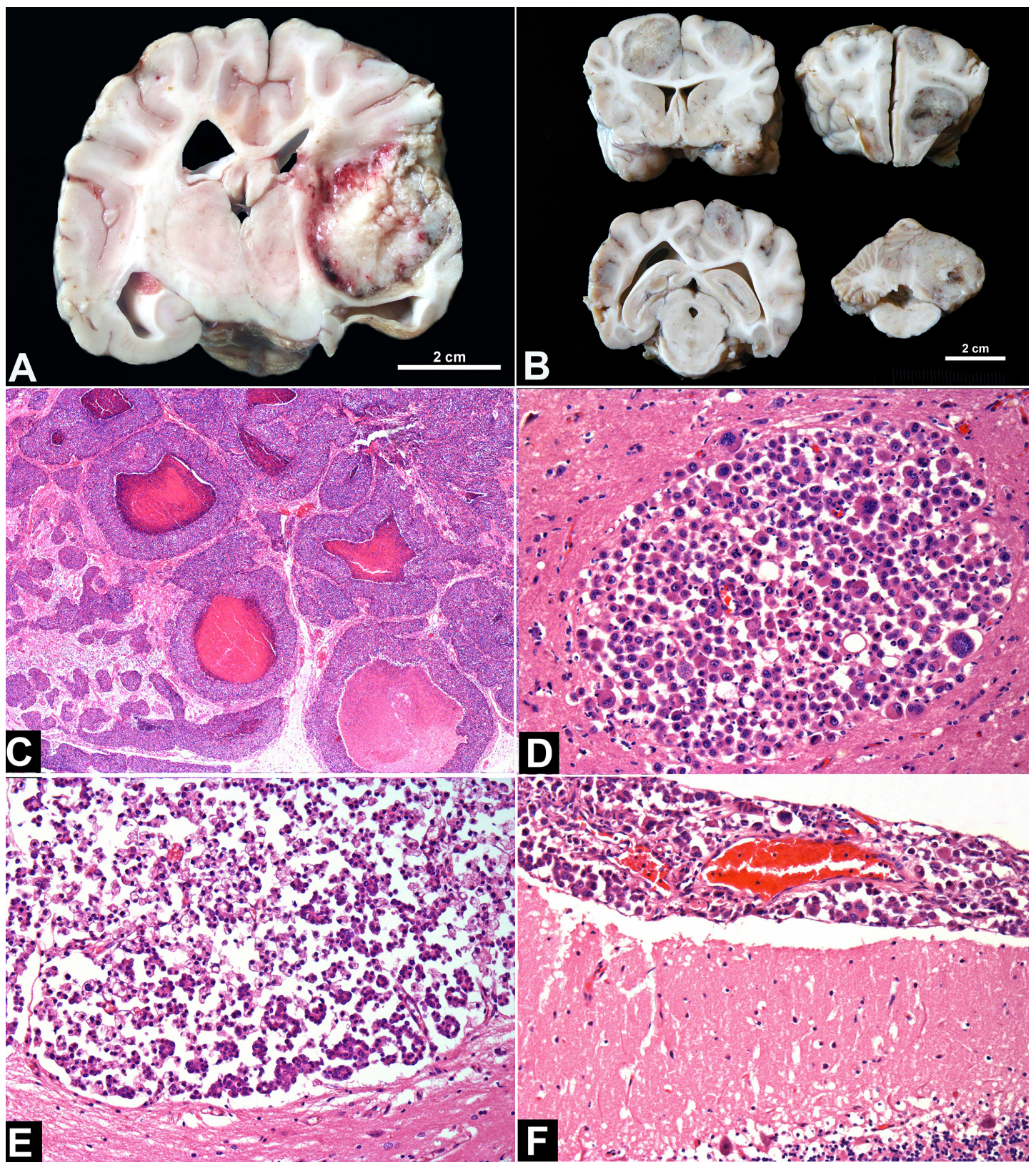

Fig.1. Mammary metastatic neoplasms in the central nervous system of dogs. (A) Solid carcinoma. Focal whitish to reddish nodule in the telencephalon. (B) Comedocarcinoma. Multifocal whitish nodules involving the telencephalon and cerebellum. (C) Comedocarcinomas were characterized by multiple nodular structures of neoplastic cells containing a central area of necrosis. HE, obj.40x. (D) Anaplastic carcinomas were highly pleomorphic and arranged in micrometastases. HE, obj.20x. (E) Micropapillary invasive carcinomas were also arranged in micrometastasis. HE, obj.20x. (F) Anaplastic carcinomas also involved the leptomeningeal spaces. HE, obj.20x. 
(Fig.1F). The mammary neoplasms with metastasis to the CNS were classified in types: anaplastic carcinoma $(n=10)$, micropapillary invasive carcinoma $(n=9)$, comedocarcinoma $(n=6)$, solid carcinoma $(n=3)$, carcinosarcoma $(n=3)$, simple tubulopapillary carcinoma $(n=3)$, adenosquamous carcinoma $(n=2)$ and mixed carcinoma $(n=1)$.

\section{Hemangiosarcoma}

A total of 15 cases of hemangiosarcomas with metastasis to the CNS were accounted. Mixed-breed $(n=9)$ and Rottweilers $(n=2)$ were the most affected. The mean age was 9.7-years-old (age range of seven to 13-years-old). Eight dogs were females and seven were males. All cases had multifocal red pinpoint to nodular $(2.5 \mathrm{~cm}$ in diameter) areas involving the telencephalon $(n=15)$, diencephalon $(n=11)$, cerebellum $(n=10)$, corpus striatum $(n=7)$, rhombencephalon $(n=5)$ and mesencephalon $(n=3)$ (Fig.2A and 2B). Microscopically, these metastases in the CNS were characterized by endothelial neoplastic cells forming vascular irregular structures frequently distended by blood and with adjacent hemorrhagic areas (Fig.2C and 2D).

\section{Lymphoma}

Lymphomas involving the CNS represented eight cases, of which multiple organs were affected, and, thus, there was a multicentric condition. Mixed-breed dogs were the most affected $(n=2)$, and the mean age was of 5.8-years-old (age range of two to 10-years-old). Male dogs were mostly affected (6 cases). The neoplasm was observed only by microscopic analysis in seven cases, of which it affected the leptomeninges of the brain $(n=7)$ (Fig.3A) and sometimes involved the neuropil blood vessels $(n=4)$ (Fig.3B). One dog presented a focal metastasis in the spinal cord (thoracic segment), characterized by a grayish soft mass which involved the dura-mater externally (extradural).

\section{Melanoma}

Metastatic melanomas in the CNS were observed in five dogs. Mixed-breed dogs $(n=3)$ were the most affected, followed by Rottweiler and Dobermann breeds. The mean age was of 10.5-years-old (age range of nine to 12-years-old). Two of these dogs were females and three males. These neoplasms were originated from the digits $(n=2)$ and oral mucosa $(n=3)$.

Grossly, all cases had focal ( 1 case) to multifocal ( 4 cases) black, occasionally white, well-defined nodules (Fig.3C). The most affected neuroanatomical location was the telencephalon $(n=5)$, followed by corpus striatum $(n=1)$, rhombencephalon $(n=1)$ and mesencephalon $(n=1)$. Histologically, the neoplastic cells varied from round to spindle, with variable amount of melanin granules in the cytoplasm, and high mitotic index (Fig.3D).
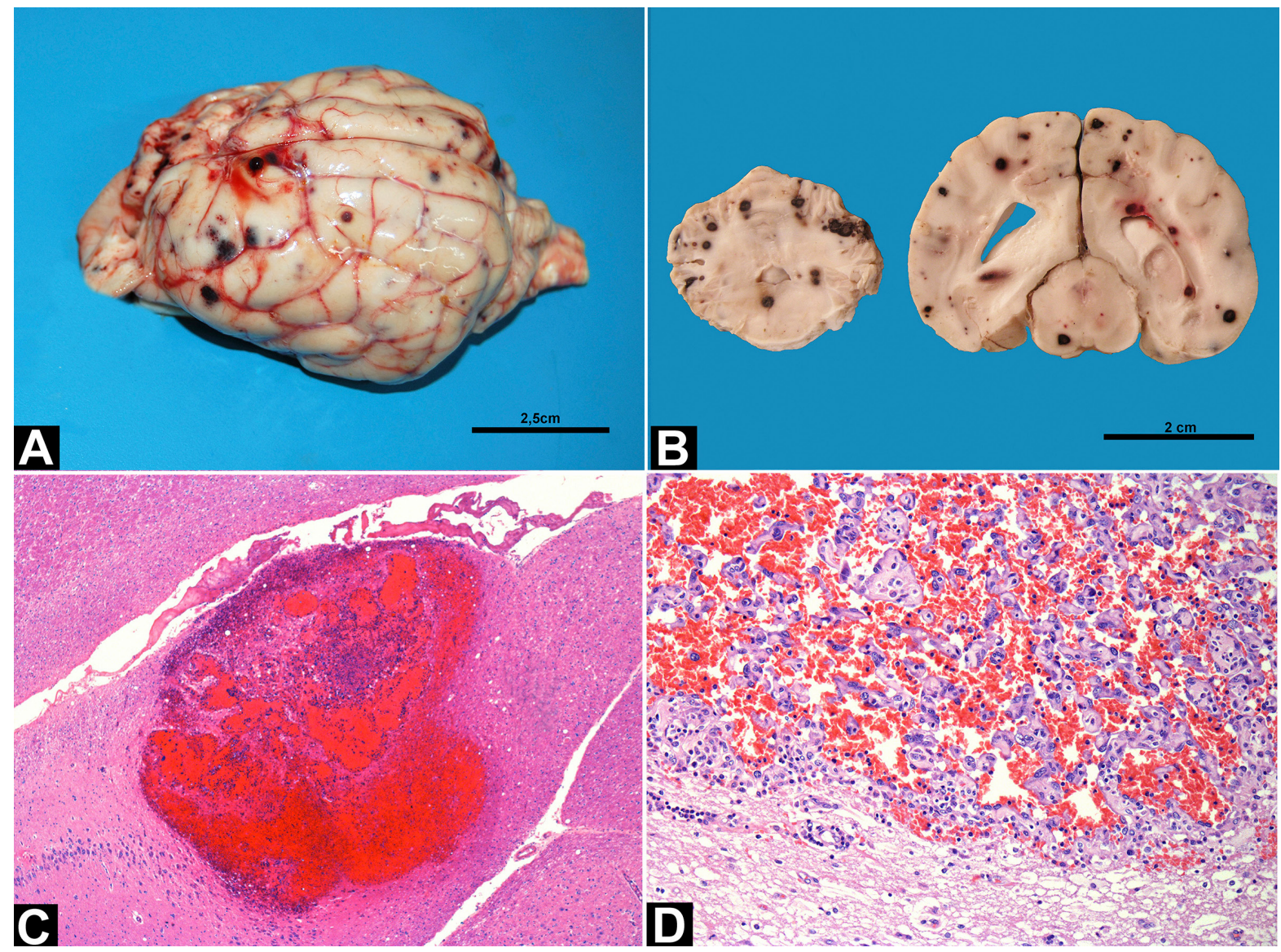

Fig.2. Metastatic hemangiosarcoma in the central nervous system of dogs. (A) Multifocal reddish pinpoint to nodular areas in the telencephalon. (B) Sagittal cut surface of the cerebellum and cerebrum showed multifocal pinpoint to nodular reddish areas, which also involved the mesencephalon. (C) The neoplastic cells were frequently obscured by severe hemorrhagic areas. HE, obj.40x. (D) The metastatic endothelial neoplastic cells were arranged in multiple irregular vascular structures, distended by blood. HE, obj.20x. 


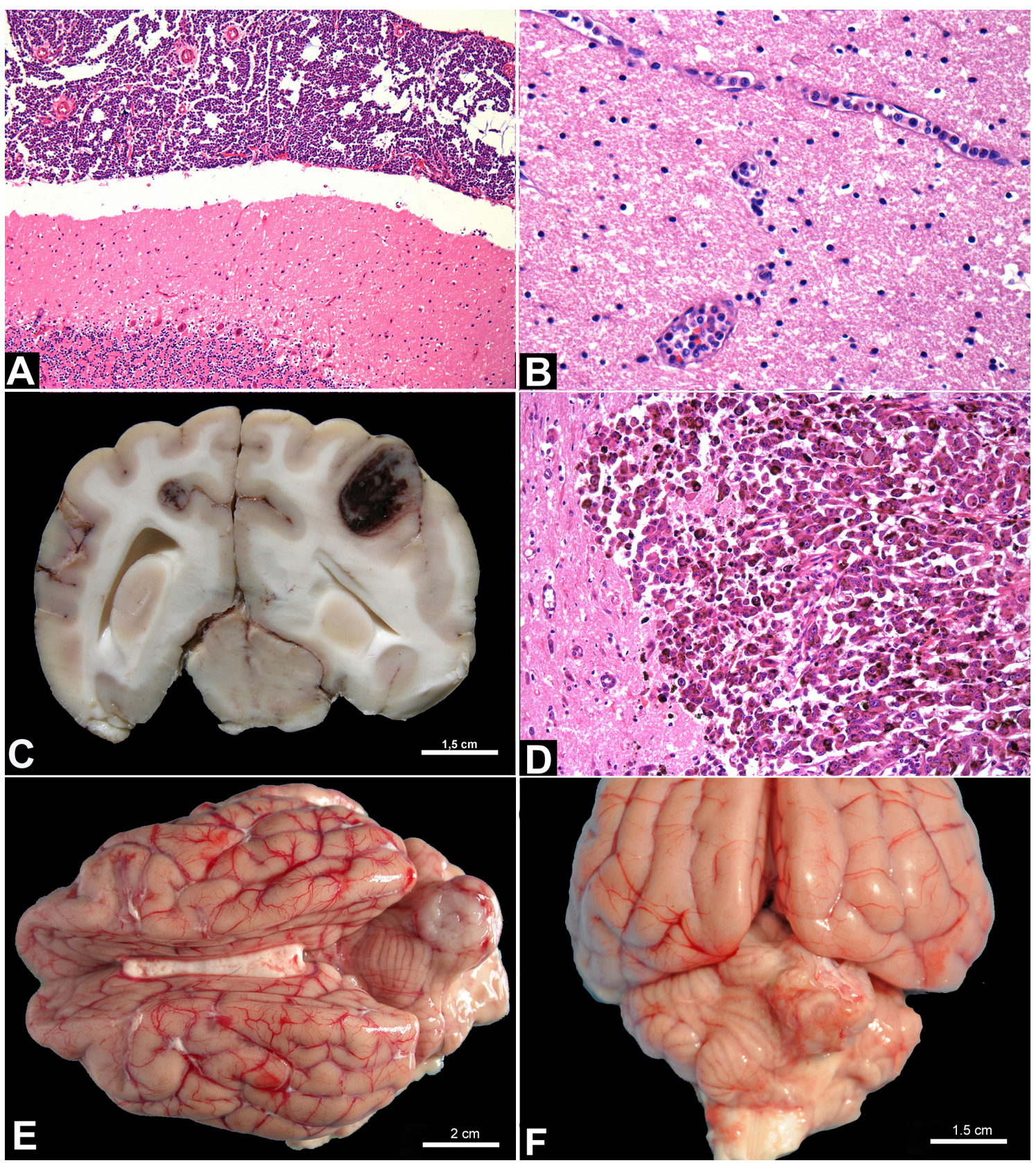

Fig.3. Multicentric lymphoma, metastatic melanoma and osteosarcoma in the central nervous system of dogs. (A) Neoplastic lymphocytes in the leptomeninges. HE, obj.40x. (B) Neoplastic lymphocytes in the leptomeninges with envolvement of neuropil blood vessels. HE, obj.20x. (C) Metastatic melanomas were characterized by multifocal black to whitish nodules in the telencephalon. (D) Neoplastic melanocytes were round to spindle and arranged in mantles, with variable amounts of melanin granules in the cytoplasm. $\mathrm{HE}$, obj.20x. (E,F) Metastatic osteosarcoma occurred in both cases as focal white nodules in the dorsal part of the cerebellum.

\section{Osteosarcoma}

Two dogs had metastasis of osteosarcoma in the CNS. One of the dogs was an eight-years-old, Rottweiler, male, with a primary thoracic limb neoplasm, while the other was a two-years-old, mixed-breed, female with a primary pelvic limb neoplasm. In both cases, a focal white and hard well- defined nodular area $(1.5 \mathrm{~cm}$ in diameter) in the dorsal part of the cerebellum (Fig.3E and 3F) was observed, with a gritty aspect on the cut surface. Histologically, the neoplastic cells were spindle-like and interspersed by bone and cartilaginous matrix.

\section{Histiocytic sarcoma}

Two dogs had metastasis of histiocytic sarcoma in the CNS (Dobermann, male, eight-years-old; and Rottweiler, female, nine-years-old). In one case, there were multifocal nodular firm and white lesions ( 1 to $2.5 \mathrm{~cm}$ in diameter) which involved the telencephalon and diencephalon (Fig.4A). The second case was characterized by pinpoint reddish lesions involving the piriform lobe (Fig.4B), which microscopically consisted of neoplastic cells located inside blood vessels (Fig.4C). These cells were round, with abundant eosinophilic cytoplasm, rounded to oval, occasionally indented, hyperchromatic nuclei. 


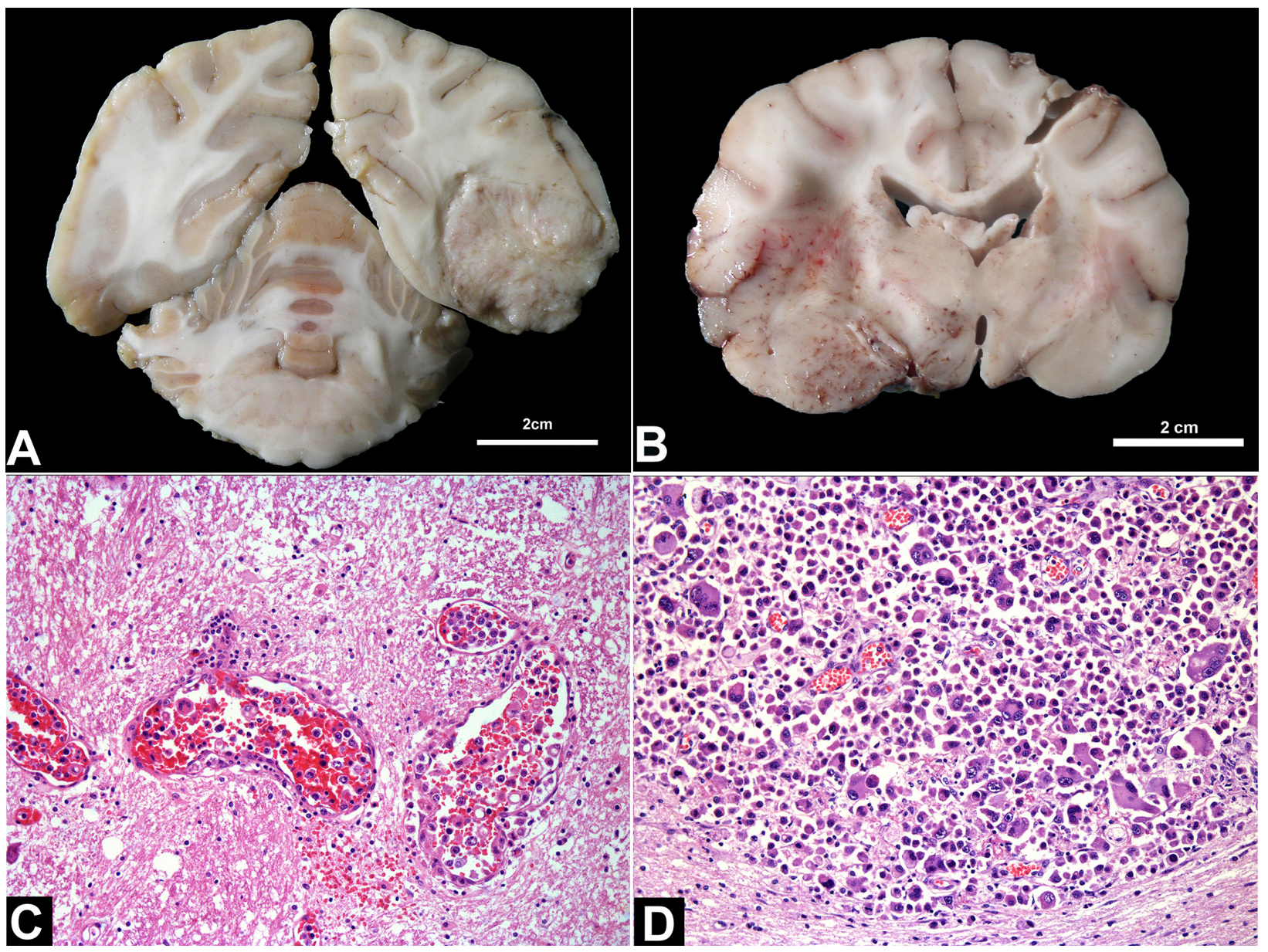

Fig.4. Metastatic histiocytic sarcoma. (A) One case had a focal nodular whitish neoplasm in the telencephalon. (B) The second case had pinpoint reddish areas involving the piriform lobe and white matter. (C) Neoplastic histiocytes were mostly located inside blood vessels. HE, obj.20x. (D) Neoplastic cells were round, with abundant eosinophilic cytoplasm, and round to oval, occasionally indented, nuclei. Numerous multinucleated neoplastic cells and mitotic figures were also observed. HE, obj.20x.

In addition to that, numerous multinucleated neoplastic cells and a high mitotic index were also observed (Fig.4D).

\section{Lung carcinoma}

Two dogs presented metastasis of lung carcinoma in the CNS (Golden Retriever and Pointer breeds). Both were females, with a mean age of 10-years-old (age range of nine to 11-years-old). One of these cases was diagnosed as a papillary pulmonary carcinoma with focal metastasis in the cerebellum (soft and white nodular area with $2.5 \mathrm{~cm}$ in diameter) (Fig.5A), while the second case was diagnosed as a large-cell carcinoma of the lung with only microscopic lesions, which were characterized by multifocal metastasis located inside blood vessels and expanding into the cerebral plexus, cerebellum, telencephalon, diencephalon, and mesencephalon (Fig.5B).

\section{Other cases}

The other seven neoplasms with metastasis to the CNS occurred individually. Among these, nasal cavity carcinoma, thyroid carcinoma and pheochromocytoma exhibited multifocal metastases in the CNS and were observed only microscopically (micrometastasis). In the other cases (cholangiocarcinoma (Fig.5C), malignant peripheral nerve sheath tumor (Fig.5D), apocrine sweat gland carcinoma and synovial sarcoma), the lesions consisted of focal nodular lesions in the telencephalon.

\section{DISCUSSION}

The diagnosis of CNS metastases in the 78 dogs of the present study was mainly based on the histopathological identification of neoplastic cells in the CNS identical to those observed in the primary sites. Metastatic neoplasms (57.77\%) were more frequent than primary neoplasms in the CNS (42.23\%). This increased frequency of metastatic neoplasms may be explained by the advances in chemotherapeutic treatments, which, in addition to a longer dog life expectancy, provides an increase in the survival time of dogs with neoplasms, and may expand the odds of a malignant neoplasm to spread to the CNS (Song et al. 2013). Another important factor is the increase in the life expectancy of dogs (Song et al. 2013), as seen in the dogs of the present study, which presented a mean age close to 10-years-old, which is similar to that described in the literature of an average age of presentation of 9.6-years-old (Snyder et al. 2008, Higgins et al. 2017).

Since the main route of metastasis to the CNS is via the hematogenous pathway, secondary neoplasms usually have a multifocal distribution (McEntee \& Dewey 2013), similar 

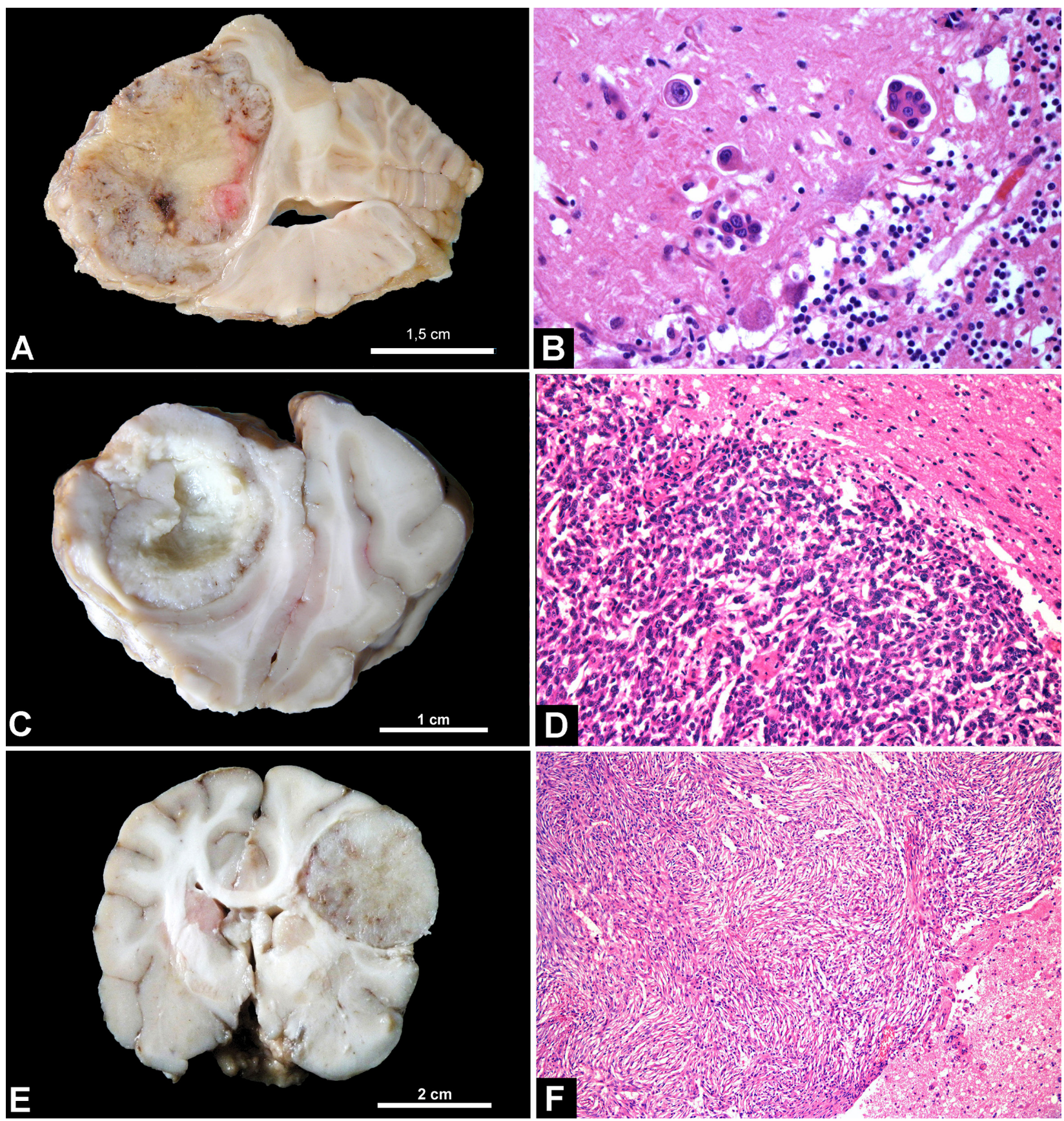

Fig.5. Metastatic lung carcinoma and other metastatic neoplasms. (A) A focal white nodular area (2.5cm in diameter) replaced part of the cerebellar hemisphere in a papillary pulmonary metastatic carcinoma. (B) Metastatic large cell carcinoma of the lung had multifocal metastasis inside blood vessels of the cerebellum. HE, obj.20x. (C) Metastatic cholangiocarcinoma and malignant peripheral nerve sheath tumor in the telencephalon. (D) Metastatic neoplastic cells infiltrated the adjacent neuropil. HE, obj.20x. (E) Metastatic cholangiocarcinoma and malignant peripheral nerve sheath tumor with focal nodular lesions in the telencephalon. (F) Metastatic neoplastic cells infiltrated the adjacent neuropil. HE, obj.10x.

to what has been observed in this study, in which $73.07 \%$ of the neoplasms were multifocal. The telencephalon is the most commonly neuroanatomic region affected by metastasis in the CNS (Santos et al. 2001, Snyder et al. 2008), as in the present study. This may be related to the abundant blood supply of this area, which favors neoplastic cell embolism, in addition to the fact that this region is the largest area of the CNS in dogs (Fenner 1990). Furthermore, the caliber of the meningeal blood vessels decreases rapidly, which facilitates the stasis of tumor emboli, mainly in the transition of the grey and white matter (Cantile \& Youssef 2016). Mixed-breed dogs were the most affected in the present study, probably because they represent a large portion of the dog population in Brazil. Female dogs were most affected than males due to the large number of cases of mammary metastatic neoplasms 
observed, since these are tumors almost exclusive of females (Oliveira et al. 2003).

Mammary gland neoplasms were the most frequent metastatic neoplasms in the CNS of dogs, differing from previous descriptions, in which hemangiosarcoma was the major metastatic CNS tumor in dogs (Snyder et al. 2008, Song et al. 2013). Predisposing factors such as unspayed female dogs and the use of progestin contraceptives, which are common in the region of the present study, are related to the occurrence of mammary neoplasms in dogs (Oliveira et al. 2003), making it the main neoplasm of dogs in Brazil (Daleck et al. 1998). The incidence of malignant neoplasms varies according to the geographic location. According to the international literature, $41 \%$ to $53 \%$ of mammary tumors of dogs are malignant (Nunes et al. 2017), while studies performed in the South of Brazil have shown a proportion of $68 \%$ and $73 \%$ of malignant mammary neoplasms (Oliveira et al. 2003, Oliveira Filho et al. 2010). There are several types of mammary carcinomas, which present differences in morphology and prognosis. The most frequent types of mammary neoplasms in the present study were anaplastic carcinoma and invasive micropapillary carcinoma. Anaplastic carcinoma is highly aggressive and invasive (malignant) and presents a high degree of metastasis to different tissues (Goldschmidt et al. 2017). In contrast, invasive micropapillary carcinoma commonly presents nodal metastasis and short global survival, which may vary from 90 to 120 days (Gamba et al. 2017). Both neoplasms are spread through the hematogenous pathway (Vandevelde et al. 2012), which was corroborated by the microscopic aspects observed in the present study of neoplastic cells within blood vessels associated to the absence of gross lesions (multiple micrometastasis). Still, the two neoplasms presented also metastasis in the meninges, characterizing a leptomeningeal carcinomatosis. In this condition, the neoplastic cells reached the meninges through blood flow and are deposited mainly in the subarachnoid space. Once these cells are established, they spread through the cerebrospinal fluid to other regions of the CNS, with a diffuse metastasis, as observed in the present study (Grossman \& Krabak 1999).

Hemangiosarcoma (HSA) is a common malignant neoplasm in dogs, and may represent up to $5 \%$ of the causes of death due to neoplasms in this species (Flores et al. 2012). It may originate in different tissues, but the spleen is the most commonly affected organ (Flores et al. 2012), being considered one of the main conditions observed in spleens after splenectomy in dogs (Bandinelli et al. 2011). This tumor is reported as the major metastatic tumor in the CNS of dogs (Snyder et al. 2008, Song et al. 2013), while in the present study HSA was the second most identified neoplasm. Involvement of the CNS in dogs with HSA was of approximately $15 \%$ in this study, which may vary from $14.2 \%$ (Waters et al. 1989) to $30 \%$ (Flores et al. 2012) in dogs that died due to HSA. These tumors may be classified as primary or secondary in the CNS (Gabor \& Vanderstichel 2006), however some authors have contested these classifications, since this neoplasm may have a multicentric behavior (Flores et al. 2012). In all cases presented here, there was a primary tumor lesion at a distant site, and, thus, all cases were considered metastatic. Grossly, this neoplasm exhibits soft reddish nodules, which correspond microscopically to the proliferation of spindle cells arranged in vascular spaces of different diameters and occasional areas of hemorrhage (Bertazzolo et al. 2005). These findings are similar to those observed in the present study, in which the neoplastic cells were distributed multifocally and predominantly around vascularized regions with associated hemorrhage. HSA metastases may occur through the lymphatic or blood vessels; however, when the CNS is involved, these occur mainly through the hematogenous route, since the CNS has an inefficient lymphatic system (Hayashi et al. 2007). In addition to the histopathology that confers a definitive diagnosis, imaging tests such as magnetic resonance are commonly used for early diagnosis of these tumors. The images are characterized by multifocal masses, with contrasting densities due to intratumoral hemorrhages (Kippenes et al. 1999).

Lymphoma is the most common hematopoietic tumor in dogs, with the generalized form as the most commonly reported (Valli et al. 2017). The involvement of the CNS by this neoplasm in dogs may be observed in 5-12\% of the cases (Higgins et al. 2017), of which the CNS may be primarily involved, when the neoplasm is located exclusively in the CNS, or affected as a secondary organ in a multicentric condition (Sisó et al. 2017). This is the most common form observed and usually involves the leptomeninges or blood vessels (Cantile \& Youssef 2016, Mandara et al. 2016), as seen in the cases described, where meninges and vessels were affected with no gross lesion observed. Instead of that, primary lymphomas are usually characterized by the formation of grayish, soft and poorly defined single masses (Higgins et al. 2017). Lymphomas can be classified into several types and it is suggested that each classification presents a distinct form of CNS distribution. However, the diffuse involvement of the meninges and the fulfillment of the lumen of blood vessels, as observed in these cases, are common in most of the lymphomas subtypes. Still other neuroanatomic regions, such as the neuropil, periventricular areas, pituitary gland and choroid plexus, are also common sites of metastases. Among lymphoma subtypes, more than 12 have been identified in the CNS. The most prevalent subtypes are peripheral T-cell lymphoma and diffuse large B-cell lymphoma (Sisó et al. 2017). In the present work, however, the immunophenotyping of lymphomas was not performed.

Melanoma is the main melanocyte tumor of dogs (Harvey et al. 1981) usually involving the digits and the oral mucosa, which is similar to the observed in this study (Goldschmidt \& Goldschmidt 2017). Around 95\% of these cases are malignant, with metastases mainly to the lymph nodes, lungs and to the brain (Bolon et al. 1990). In humans, $15.7 \%$ of the metastatic CNS tumors have been found to be melanomas (Vieth \& Odom 1965), whereas in dogs this corresponds to 3.4\% (Snyder et al., 2008) and 7.8\% (Song et al. 2013), which are similar to the observed in the present study (6.41\%). Primary melanomas in the CNS are rare and usually are limited to the leptomeninges (Kim et al. 2009). However, in the present study, all cases formed well-defined multifocal nodules involving the neuropile. Differentiation of primary and metastatic melanoma may be difficult and depends mainly on the absence or presence, respectively, of oral or skin neoplasms (Kim et al. 2009), as evidenced in this study where all cases presented primary digital or oral mucosa neoplasms. The metastases of melanoma in the CNS are generally distributed multifocally and are grossly pigmented - except for amelanotic melanomas - while 
microscopically it presents similar features to the primary tumor (Summers et al. 1995), as in the present study.

Osteosarcoma is the most common bone neoplasm of dogs, and, frequently, affects the appendicular skeleton of large and giant breeds (Tilley \& Smith 2015). These are aggressive tumors that may cause local bone destruction, invade the adjacent soft tissues, and have a high metastatic potential. The lungs are the main organ affected by metastasis of osteosarcoma, and metastasis to the CNS are not common (Trost et al. 2012). In a previous study that evaluated 43 osteosarcomas in dogs submitted to necropsy, only one case presented a CNS metastasis (Trost et al. 2012), which is similar to the present study, where only two cases of 78 had osteosarcoma metastasis. In both cases, these were focal and had the same distribution (dorsal part of the cerebellum), suggesting a possible predilection for this region.

Histiocytic sarcoma may affect the CNS primarily or as a metastatic spread. Primary CNS histiocytic sarcoma often originate in the leptomeninges, or forming a focal and solitary subdural mass, and rarely presents extracranial metastasis (Moore 2014). In the two cases presented here, lesions were multifocal in the neuropil and several organs were also affected, which was consistent with a metastasis to the CNS. Histiocytic sarcoma is considered one of the most frequent metastatic tumors in the CNS (Vandevelde et al. 2012), differing from the present report, where only two cases were observed. This low frequency observed here may be possibly related to the low total number of cases of histiocytic sarcoma in the population studied (12 cases). However, its relative frequency was similar to that observed in more frequent cases as hemangiosarcomas and mammary carcinomas. Hayden et al. (1993) described the thalamus, hippocampus and the lumen of vessels as common sites of histiocytes metastasis. These regions are similar to those found in this study, where telencephalon, diencephalon and the lumen of blood vessels were the most affected areas. This condition is characteristic of large or giant breeds, such as Dobermann and Rottweiler (Califford \& Skorupsli 2010), as identified in the present study.

Lung carcinomas are described as one of the major metastatic CNS neoplasms of humans (Santos et al., 2001). However, in dogs, these neoplasms are rarely observed as metastasis in the CNS, with a frequency of $1.7 \%$ (Snyder et al. 2008), which is similar to that observed in this study $(2.56 \%)$. The frequency of primary lung cancers in dogs is low compared to humans, and secondary lung neoplasms are most common. This difference may be explained by the high frequency of lung neoplasms associated with smoking practices in humans (Zamboni 2002). Two distinct types of pulmonary neoplasms were observed: papillary carcinoma and large cell carcinoma. These had different patterns of metastasis: while the papillary carcinoma had a focal area of metastasis, the large cell carcinoma was observed diffusely inside blood vessels in the CNS.

\section{CONCLUSIONS}

Metastatic neoplasms were most frequent than primary neoplasms in the CNS of dogs.

The mean age of dogs included in this study was of 9.55-years-old.

Females were mostly affected than males, due to a higher frequency of mammary tumors.
Neoplasms were mostly multifocal, and the telencephalon was the most commonly affected neuroanatomic region.

Mammary neoplasms were the most frequent, and the most commonly observed types were anaplastic carcinoma, invasive micropapillary carcinoma and comedocarcinoma. In the cases of anaplastic carcinoma and micropapillary carcinoma, a multifocal microscopic involvement of the CNS was observed, with an absence of gross lesions.

Hemangiosarcoma was the second most common neoplasm, with a multifocal involvement.

Lymphoma predominantly involved the meninges and the lumen of blood vessels.

The collection and pathological analysis of metastatic neoplasms involving the CNS provides important data to clinical veterinarians, when these are facing conditions with neurological clinical signs, in order to obtain a conclusive diagnosis. It is essential that metastatic neoplasms are considered as differential diagnosis in these cases, aiming prevention and appropriate treatments.

Conflict of interest statement.- The authors have no competing interests.

\section{REFERENCES}

Bandinelli M.B., Pavarini S.P., Oliveira E.C., Gomes D.C., Cruz C.E.F. \& Driemeier D. 2011. Estudo retrospectivo de lesões em baços de cães esplenectomizados: 179 casos. Pesq. Vet. Bras. 31(8):697-701. <http://dx.doi.org/10.1590/ S0100-736X2011000800011>

Bertazzolo W., Dell’Orco M., Bonfanti U., Ghisleni G., Caniatti M., Masserdotti C., Antoniazzi E., Crippa L. \& Roccabianca P. 2005. Canine hemangiosarcoma: cytologic, histologic, and immunohistochemical correlations. Vet. Clin. Pathol. 34(1):28-34. <http://dx.doi.org/10.1111/j.1939-165X.2005. tb00005.x> <PMid:15732014>

Bolon B., Mays M.B.C. \& Hall B.J. 1990. Characteristics of canine melanomas and comparison of histology and DNA ploidy to their biologic behavior. Vet. Pathol. 27(2):96-102.<http://dx.doi.org/10.1177/030098589002700204> <PMid:2345943>

Califford C.A. \& Skorupsli K.A. 2010. Histiocitic diseases. In: Henry C.J. \& Higginbotham M.L. (Eds), Cancer Managment in Small Animal Practice. W.B. Saunders, Philadelphia. 432p.

Cantile C. \& Youssef S. 2016. Nervous system, p.250-406. In: Maxie M.G. (Ed), Jubb, Kennedy and Palmer's Pathology of Domestic Animals. Vol.1. 5th ed. Saunders Elsevier, Philadelphia. 1250p. <http://dx.doi.org/10.1016/ B978-0-7020-5317-7.00004-7>.

Daleck C.R., Franceschini P.H., Alessi A.C., Santana A.E. \& Martins M.I. 1998. Aspectos clínico e cirúrgicos do tumor mamário canino. Ciência Rural 28(1):95-100. <http://dx.doi.org/10.1590/S0103-84781998000100016>

Fenner W.R. 1990. Metastatic neoplasms of the central nervous system. Seminars Vet. Surg. 5(4):253-261. <PMid:2075305>

Flores M.M., Panziera W., Kommers G.D., Irigoyen F., Barros C.S.L. \& Fighera R.A. 2012. Aspectos epidemiológicos e anatomopatológicos do hemangiossarcoma em cães: 40 casos (1965-2012). Pesq. Vet. Bras. 32(12):1319-1328. <http:// dx.doi.org/10.1590/S0100-736X2012001200017>

Gabor L.J. \& Vanderstichel R.V. 2006. Primary cerebral hemangiosarcoma in a 6-week-old dog. Vet. Pathol. 43(5):782-784. <http://dx.doi.org/10.1354/ vp.43-5-782><PMid:16966462>

Gamba C.O., Ferreira E., Salgado B.S., Damasceno K.A., Bertagnolli A.C., Nakagaki K.Y.R. \& Cassali G.D. 2017. Neoplasias malignas, p.84-91. In: Cassali G.D. (Ed), Patologia Mamária Canina: do diagnóstico ao tratamento. MedVet, São Paulo. 209p. 
Goldschmidt M.A. \& Goldschmidt K.H. 2017. Epithelial and melanocytic tumors of the skin, p.88-142. In: Meuten D.J. (Ed), Tumors of Domestic Animals. 5th ed. Iowa State Press, Ames.

Goldschmidt M.H., Peña L. \& Zappulli V. 2017. Tumors of the mammary gland, p.723-766. In: Meuten D.J. (Ed.), Tumors of Domestic Animals. 5th ed. Iowa State Press, Ames.

Grossman S.A. \& Krabak M.J. 1999. Leptomeningial carcinomatosis. Cancer Treat. Revs 25(2):103-119. <http://dx.doi.org/10.1053/ctrv.1999.0119> $<$ PMid:10395835>

Harvey H.J., MacEwen E.G., Braun D., Patnaik A.K., Withrow S.J. \& Jongeward S. 1981. Prognostic criteria for dogs with oral melanoma. J. Am. Vet. Med. Assoc. 178(6):580-582. <PMid:7263464>

Hayashi A.M., Matera J.M., Hagen S.C.F., Maluenda A.C.H., Maiorka P.C. \& Sá L.R.M. 2007. Hemangiossarcoma metastático no sistema nervoso central de um Beagle: considerações sobre a apresentação clínica e anatomopatológica. Pesq. Vet. Bras. 27:30-31.

Hayden D.W., Waters D.J., Burke B.A. \& Manivel J.C. 1993. Disseminated malignant histiocytosis in a Golden retriever: clinicopathologic, ultrastructural, and immunohistochemical findings. J. Vet. Pathol. 30(3):256-264. <http:// dx.doi.org/10.1177/030098589303000306> <PMid:8333107>

Higgins R.J., Bollen A.W., Dickinson P.J. \& Sisó-Lionch S. 2017. Tumors of the nervous system. In: Meuten D.J. (Ed), Tumors of Domestic Animals. 5th ed. Iowa State Press, Ames.

Kim D.Y., Royal A.B. \& Villamil J.A. 2009. Disseminated melanoma in a dog with involvement of leptomeninges and bone marrow. Vet. Pathol. 46(1):80-83. <http://dx.doi.org/10.1354/vp.46-1-80><PMid:19112120>

Kippenes H., Gavin P.R., Bagley R.S., Silver G.M., Tucker R.L. \& Sande R.D. 1999. Magnetic resonance imaging features of tumors of the spine and spinal cord in dogs. Vet. Radiol. Ultrasound 40(6):627-633. <http://dx.doi. org/10.1111/j.1740-8261.1999.tb00890.x><PMid:10608691>

Mandara M.T., Motta L. \& Calò P. 2016. Distribution of feline lymphoma in the central and peripheral nervous system. Vet. J. 216:109-116. <http:// dx.doi.org/10.1016/j.tvjl.2016.07.013><PMid:27687936>

McEntee M.C. \& Dewey C.W. 2013. Tumors of the nervous system, p.768. In: Withrow S., Vail D. \& Page R. (Ed), Animal Clinical Oncology. 5th ed. W.B. Saunders, Philadelphia.

Moore P.F. 2014. A review of histiocytic diseases of dogs and cats. Vet. Pathol.51(1):167-184.<http://dx.doi.org/10.1177/0300985813510413> <PMid:24395976>

Nunes F.C., Campos C.B. \& Bertagnolli A.C. 2017. Aspectos epidemiológicos das neoplasias mamárias caninas, p.27-32. In: Cassali G.D. (Ed), Patologia Mamária Canina: do diagnóstico ao tratamento. MedVet, São Paulo. 209p.
Oliveira Filho J.C., Kommers G.D., Masuda E.K., Marques B.M.F.P.P., Fighera R.A., Irigoyen L.F. \& Barros C.S.L. 2010. Estudo retrospectivo de 1.647 tumores mamários em cães. Pesq. Vet. Bras. 30(2):177-185. <http:// dx.doi.org/10.1590/S0100-736X2010000200014>

Oliveira L.O., Oliveira R.T., Loretti A.P., Rodrigues R. \& Driemeier D. 2003. Aspectos epidemiológicos da neoplasia mamária canina. Acta Scient. Vet. 31(2):105-110.

Santos A.J., Franco C.M.R., Borges L.R.R., Malheiros S.M.F. \& Gabbai A.A. 2001. Metástases cerebrais. Revta Neurociências 9(1):20-26.

Sisó S., Marco-Salazar P., Moore P.F., Sturges B.K., Vernau W., Wisner E.R., Bollen A.W., Dickinson P.J. \& Higgins R.J. 2017. Canine nervous system lymphoma subtypes display characteristic neuoanatomical patterns. Vet. Pathol. 54(1):53-60. <http://dx.doi.org/10.1177/0300985816658101> <PMid:27511313>

Snyder J.M., Lipitz L., Skorupski K.A., Shofer F.S. \& Van Winkle T.J. 2008. Secondary Intracranial Neoplasia in the Dog: 177 cases (1986-2003). J. Vet. Intern. Med. 22(1):172-177. <http://dx.doi.org/10.1111/j.1939-1676.2007.0002. $\mathrm{x}><$ PMid:18289306>

Song R.B., Vite C.H., Bradley C.W. \& Cross J.R. 2013. Postmortem evaluation of 435 cases of intracranial neoplasia in dogs and relationship of neoplasm with breed, age, and body weight. J. Vet. Intern. Med. 27(5):1143-1152. <http://dx.doi.org/10.1111/jvim.12136><PMid:23865437>

Summers B.A., John F.C. \& Lahunta A. 1995. Veterinary Neuropathology. 6th ed. Mosby, Missouri. 527p.

Tilley L.P. \& Smith F.W.K. 2015. Consulta Veterinária em 5 Minutos: Espécies Canina e Felina. 5ํe ed. Manole, São Paulo. 1560p.

Trost M.E., Kommers G.D., Brown C.C., Barros C.S.L., Irigoyen L.F., Fighera R.A., Inkelmann M.A. \& Silva T.M. 2012. Primary bone neoplasms in dogs: 90 cases. Pesq. Vet. Bras. 32(12):1329-1335. http://dx.doi.org/10.1590/ S0100-736X2012001200018.

Valli V.E.O., Kiupel M. \& Bienzle D. 2017. Hematopoietic system, p.102-268. In: Maxie M.G. (Ed), Jubb, Kennedy and Palmer's Pathology of Domestic Animals. Vol.3. 5th ed. Saunders Elsevier, Philadelphia. 868p.

Vandevelde M., Higgins R.J. \& Oevermann A. 2012. Veterinary Neuropathology: essentials of theory and practice. Wiley-Blackwell, USA, p.129-156.

Vieth R.G. \& Odom G.L. 1965. Intracranial metastases and their neurosurgical treatment. J. Neurosurg. 23(4):375-383. <http://dx.doi.org/10.3171/ jns.1965.23.4.0375><PMid:5322208>

Waters D.J., Hayden D.W. \& Walter P.A. 1989. Intracranial lesions in dogs with hemangiosarcoma. J. Vet. Intern. Med. 3(4):222-230.<http://dx.doi. org/10.1111/j.1939-1676.1989.tb00861.x><PMid:2585369>

Zamboni M. 2002. Epidemiologia do câncer do pulmão. J. Pneumol. 28(1):4147. <http://dx.doi.org/10.1590/S0102-35862002000100008> 